\title{
Adaptation of Cities to Climate Change (Best Practices Review)
}

\author{
Zinaida Ivanova ${ }^{1, *}$, and Michael Eichner ${ }^{2}$ \\ ${ }^{1}$ Moscow State University of Civil Engineering, Yaroslavskoye shosse, 26, Moscow, 129337, Russia \\ ${ }^{2}$ German University in Cairo - GUC, New Cairo City, Egypt
}

\begin{abstract}
The authors of the article are raising current issues related to climate change and global warming. Not all the countries are responding to these processes the same way and undertake joint complex efforts to mitigate climate change impacts. The authors have analyzed the existing legislations and actions for adaptation to climate change in the EU and separate European countries. "Covenant of Mayors", ADAPT program, Joint Programming Initiative Urban Europe are considered in detail. Informational and awareness-raising work of state and educational entities is one of the main necessary actions to mitigate climate change negative impacts. The article presents the results of the opinion poll made by the European Social Survey, "Russian Public Opinion Research Center" (JSC "VCIOM") and the investigations of German State Development Bank KfW on how citizens perceive climate change processes, their sense of personal responsibility and personal reaction. Also a brief review of educational programs of builders, urban developers and architects in European and Russian universities is added to the article. The conclusion of the authors is as such: it is necessary to intensify legislative measures for adaptation of cities to climate change, the stronger control of the amount of carbon dioxide emissions and coordinated actions in one region are needed. It is necessary to pay careful attention to climatic education of the students - future builders and urban developers.
\end{abstract}

\section{Introduction}

Climate change, global warming and COVID-19 pandemic are the priority issues of today, which need a prompt response and change of approach to urban development and planning. The world is facing unforeseen processes, which maybe have been forecasted, but they didn't call for instant response then. Today we don't have time for preparation. It is necessary to develop joint strategies and implement them, to take actions for adaptation of cities to these processes in order to address wide negative consequences. In the EU as a whole and in separate European countries prompt measures are taken to combat global warming impacts. Among them are: reduction of greenhouse gases emission (from industrial facilities and transport operating on non-renewable energy resources), design of energy-efficient buildings and territories, informational and educational activities with the population [1]. As

\footnotetext{
${ }^{*}$ Corresponding author: zinaida.i.ivanova@gmail.com
} 
a result of the actions taken in the EU countries the most progressive legislation in the world is introduced in the field of combating global warming. The highest level of concern about climate change impacts is registered there among the population. The highest concern was registered in Portugal (51\%) and Spain (48\%), and the lowest in Russia (14\%), Poland (15\%) and Estonia (15\%). The sense of personal responsibility for mitigating climate change impacts was highest in France and Switzerland (with average rate close to 7 according to 010 scale) and the lowest in the Czech Republic and Russia (both with average rate lower than 4) [2]. Moreover opinion polls made by VCIOM in Russia have given a more distressing scene of public conscience state about climate change.

\section{Research Tasks and Methods}

The aim of the given article is to analyze the actions for combating climate change negative impacts which were implemented in the EU countries over the past decade, to observe the steps made in frames of joint agreements between the European countries. One of the research methods is document analysis. The authors have examined the legislations of the European countries and Russia in the field of environmental protection, the EU programs on adaptation of cities to climate change, the solutions of state and municipal authorities in this regard. The second method is sociological research using questionnaire. The article gives the results of opinion polls conducted in 2018 and 2020. The authors also have analyzed educational programs of some European universities and the Moscow State University of Civil Engineering (Russia).

\section{Literature review}

Today there are a lot of researches about climate change. The issue is so acute that many countries, first of all European countries, are actively searching for alternatives to global climate change. Researchers from Germany believe that successful control of city climate change needs cooperation of different public sectors because no sector can implement policy and programs alone and solve these different but interconnected problems [3]. Obviously it is possible to solve climate change problem only in cooperation because it's a planet wide problem. And also a single approach to solution of this problem, consensus concerning climate change and unite measurement instruments are needed [4-5]. Researchers from different countries are putting this opinion forth meaning cooperation and consensus between representatives from different continents: both Europe and Asia. In order to predict the consequences of climate change it's necessary to constantly monitor changes and set a forecast for the future [6]. A group of scientists from Sweden together with a climatic service Urban SIS have offered historical and modelled future data reduced to the resolution $1 \mathrm{~km} \mathrm{x}$ $1 \mathrm{~km}$ for separate European cities. The scaled down data may be further used as opening data for modelling air quality and hydrological effects. Such models allow working out a strategy in regions, groups of cities, city regions having similar conditions. It will also allow integrating into city plans the measures to mitigate the effects [7]. A group of authors from Netherlands and Germany have researched the united efforts of several medium-sized cities most dependent on water resources. The authors note that sustainable management of water resources remains critically important for city climate stability [8]. Digital technologies provide great support in solving climate change problems. Scientists from Malaysia, Hong Kong and India believe digitalization is a key factor of the sustainable development of city social and economic dynamics with potential to create a climatically friendly city environment and society. The authors provide their analysis of the modern tendency for digital revolution in adaptation to climate change and discuss possible problems of 
digitalization. Digital technologies can help «in supporting more effective early warning and emergency response systems, enhancing food and water security, improving power infrastructure performance, enabling citizen engagement and participatory adaptation measures and minimizing the impacts of climatic hazards» [9].

A range of researches is dedicated to enforcement of the social character of measures to combat impacts of climate change. The society should pay main attention to the most vulnerable citizens. Social assistance and funding to be provided by the municipalities could mitigate negative social consequences. [10-12]. Citizens can also participate in decision making on urban planning projects that can have a negative environmental impact [13-14].

\section{Research results}

Over the past decades anomalous processes of global warming have intensified. It is a real threat to the whole planet ecosystem. Yearly average temperature is increasing, the amount of snow is decreasing and glaciers are melting, water quantity in oceans increase. Beginning from 1979 the area of arctic seawater ice has been shrinking by 1.07 million square meters a decade. Also ice is melting on continents. For example, in Iceland the total ice area is rapidly decreasing. About $75 \%$ of warming is due to carbon dioxide. Australian scientists forecast global destruction of the civilization we are used to beginning from 2050.

If we don't take active actions to reduce air emissions the average see level will rise by $24-30 \mathrm{~cm}$ to 2065 and by $40-63 \mathrm{~cm}$ to 2100 taking into account the concentration of greenhouse gases in the atmosphere today and the fact that the emissions are continuing. It will affect the state of cities and settlements, life-support system and people's health.

Today 402 cities in the world have officially undertaken 1036 obligations in combating climate change in frames of Nongovernmental platform combating climate change UNFCC 2015 (United Nations Framework Convention on Climate Change) and 63 cities have undertaken obligations in frames of C40 - network of the world's megacities committed to addressing climate change (Large Cities Climate Leadership Group) [15].

The carried out researches on combating negative effects of climate change show that the EU countries are solving these problems most efficiently. For quite some time the European city development align with a strategy which is both aimed at climate protection and climateadaptation of a city territory as well as social modernization in urban development. Territorial closeness of the EU countries provides the possibility of combating climate change impacts. The Lisbon Treaty and a new EU strategy introduced a new dimension - Territorial Agenda of the European Union 2020. The climate change impacts go beyond administrative boundaries that are why new forms of cooperation between countries and regions are being developed.

In 2008 "Covenant of Mayors" of European cities was concluded supporting the actions of local authorities in the sphere of climate change and energy sector. In 2013 the European Commission adopted the EU strategy of adaptation to climate change (ADAPT). In frames of this program the European-wide platform for adaptation to climate was created (ClimateADAPT). This platform provides data about current and forecasted climatic dangers and it is intended to raise public awareness about adaptation and requisite measures. In March 2014 in frames of the "Covenant of Mayors" an initiative on adaptation to climate change "Mayors Adapt" have started. The majority of the European cities have joined this Initiative. Cities interchange information about the influence of climate change; interchange their technologies and experience of solving these problems. They hold joint activities to reduce climate change impacts. The aim of the "ADAPT" majors is to increase the support of local activity, to provide platform for more active interaction between the cities as well as to take joint actions. The Territorial Agenda of the European Union calls for better coordination between the EU cities which are classified as problem city territories [16]. For example, in 
the recent five years flood in Upper Tyrrhenian region has caused damage to the tune of 1 billion Euros. The reason for the damage is over waterproofing of cities, which intensifies negative impacts of weather elements and gives rise to catastrophic floods. Municipalities of coastal settlements taking part in joint actions receive support in preparing and implementing local adaptation plans, which should have a direct positive influence on safety of both people and infrastructure. In particular the decision was taken to create a drainage infrastructure, which should raise flood resistance of the region [17]. Another thread supported by the Mayors Adapt program is urban greening. The absence of landscaped areas in cities leads to temperature increase (urban heat island effect). A great amount of soil surface sealing also reduces natural drainage, which can lead to serious city floods during heavy rains. City management aimed at solving climate change problems by developing green infrastructure is leading to increase of city sustainability and also improves the air quality, citizens' health and citizens' life quality as a whole.

The European Commission has developed several financing programs for investigations and innovations for city adaptation to climate change impacts. The EU investigation program "Horizon 2020" for 2018-2020 included such topics as "Strengthening international cooperation on sustainable urbanization: nature-based solutions for restoration and rehabilitation of urban ecosystems (RIA)", "Innovative solutions for inclusive and sustainable urban environments". "Horizon 2020" makes easier the development of instruments and approaches to understand and implement necessary actions for adaptation to climate change.

The service investigating climate change named Copernicus $(\mathrm{C} 3 \mathrm{~S})$ provides information and knowledge about climate change using available, reliable and time-sensitive information sources. Copernicus is monitoring software of the EU territory. It consists of a complex set of systems, which collect data from several sources: Earth observatory satellites and on-site sensors such as ground stations, onboard and sea sensors. The systems process data and provide users with information via a set of services, which include six thematic fields: land, sea, atmosphere, climate change, emergency control and safety. The service offers key indicators of climate change measurements to support European policy and develops specialized climatic data management for city regions [18].

Joint Program "Urban Europe" is coordinating investigations in member- states and finances investigations of climate change in some definite cities. Climate-KIC is one of six communities of knowledge and innovations created by the European institute for Innovations and Technologies. It is aimed to develop progressive innovative climatic technologies and bring them to market. Moreover "The Joint Research Center of the European Commission" (JRC), ESPON 2020 and COST are integrated research programs of interdisciplinary and transboundary cooperation financed by the European Union. They deal with the issues of cities' sustainability and adaptation.

As a result the branched complex system of climate change comprehensive investigation and efficient control allows European cities adapting to the changes caused by climatic anomalies in due time.

National programs of climate change combat in European countries are of great interest. Beginning from 1976 in Germany the further development and change of climate policy and construction legislation was caused by global ecological disasters, such as the one happened in Fukushima. After it new possibilities for environmental and climate protection in urban planning have become available. The Federal Government of Germany has adopted a wide range of laws and regulatory acts on climate change and greenhouse gas emissions. It has led to a new model of city development compatible with climate change, which also includes "energy recovery of a city". Though cities and municipalities in Germany as well as their geographic, social and economic conditions differ, new concepts and instruments have appeared which are efficient for urban planning and adaptation to climate change on the 
whole German territory. Municipal activity consists of "City strategies for climate change" and "Energy city renovation". Supporting environmental friendly pedestrian, bicycle and public local transport, optimization of city energy supply with district heating or decentralized production and energy-saving reconstruction of existing buildings are urban planning spheres where climate protection may be taken into account first of all. Isolation of buildings and heating system development are also the examples of climate protection measures. Development of landscaped areas, passages with cold air and color surface of buildings are the examples of measures to adapt to the climate. The German Council on sustainable construction DGNB has developed the basis for climatically neutral buildings and town-planning territories. DGNB methodologies for climatically neutral buildings and town-planning territories make great contribution to provide practically possible decarburization of city territories to 2050 . The methodology includes different social factors having positive effect on reducing carbon dioxide emission.

Public and governmental active participation in developing urban plans should greatly increase recognition of this tendency among population. According to the investigation "Energy Transition Barometer" (Energiewendebarometer 2019) presented by the State Development Bank KfW in August, during opinion poll $78 \%$ of households stated they would like to change their energy consumption somehow. Herewith every second household (52\%) is ready to increase a share of renewable energy sources in their home energy balance, though their use is yet more expensive than fossil energy. Almost a half of households $(46 \%)$ answered they would like to produce renewable energy themselves, each forth $(26 \%)$ is planning to buy an electric car over the coming decade [19].

The Government of Germany is introducing a number of legislative measures according to which Germany should become greenhouse gases neutral according to carbon neutrality principle. It is supposed to reduce CO2 emissions in Germany by $55 \%$ to 2030 as compared to 1990 .

The Russian Federation also takes measures to adapt to climate change. Although Russia is one of those countries where such measures are quite slow in coming. In 2019 the National Plan of Paris Climate Agreement implementation was developed which is aimed at meeting the threats of climate change and raising adaptability to its adverse effects. This document assigns stage-by-stage measures up to 2020. Branch and regional adaptation plans should be developed in the coming three years, though no measures are given in the plan. We should mention a very slow nature of the actions suggested and absence of definite instructions to regional authorities.

The concern about climate change impacts is not high enough on different levels of public conscious beginning from representatives of state and municipal government and ending with common citizens. Regular opinion polls by the European Social Survey Center show the low level of awareness about climate change impacts in a number of countries. In Russia the percentage of people believing the climate is definitely not changing is higher than anywhere else in Europe - 9,1\%. As a comparison, in Ireland, Finland and Sweden it is $0,5 \%$, in Belgium - $0,6 \%$ [2].

According to the data of the opinion poll in 2020 by the "Russian Public Opinion Research Center" (JSC "VCIOM") 52\% of responded Russians don't think global warming is a serious problem, $40 \%$ believe it is a fringe and overhyped problem [20].

$60-70 \%$ of respondents are not ready to pay for implementation of alternative energy sources and energy efficiency improvement. We are talking about prices increase for fuel, housing and utilities services, energy, use of cars and public transport. If we compare it to the results of the European Social Survey we can also see, that the support of renewable energy sources financing is very low in Russia. The most popular energy sources here are coal and natural gas, which produce the highest carbon dioxide emissions [2] 
Another problem related to combating climate change impacts is behavior models formation, which supposes personal responsibility for what is happening. In frames of the $8^{\text {th }}$ round opinion poll of the European Social Survey questions about sense of personal responsibility for reducing climate change impacts were asked. The respondents were offered eleven-point scale from 0 (absolutely no) to 10 (very much). The sense of personal responsibility (personal standards) was the highest in France, Switzerland, Germany (with the values close to 7) and the lowest in the Czech Republic and Russia (average value lower than 4) [2].

Personal responsibility is formed as a result of outreach and awareness-raising work. Improvement of basic and professional education, climatic awareness in schools and universities are of major importance for uniting and coordinating different countries.

The authors of the given article have studied educational programs of constructors, architects and urban developers (bachelors and masters) in Moscow State University of Civil Engineering. There are no academic disciplines focused on climate change in the curriculum for students majoring in restoration and reconstruction. Such disciplines as "Climatology", "Biosphere compatibility of cities" and "Sustainable development of territories" are added to the Urban Development curriculum designated for bachelor and master students. Students, majoring in architecture, study the "Climate and architecture" discipline. In our the sociological survey of third-year students- architects at Moscow State University of civil engineering in May 2020, we have found that $93.3 \%$ of respondents who studied this discipline answered "Yes" to the question: "In your opinion, does architecture influence the environment and the climate change ". Students are well aware of the problem and are aware of its importance. $64 \%$ of student respondents try to consider climate protection factors in their training projects.

In Russia the sphere of higher education has not yet realized the necessity to improve climatic education for future engineers, builders, urban developers and architects. Moreover the educational level is the strongest indicator of the awareness about climate change and further actions to mitigate the consequences. The role of universities in education concerning climate change sphere is very important. Climate change education is of great importance also for scientific, social and political tasks the world is facing today. Europe has accumulated great experience in cclimate change education. The universities of the EU include these problems into their syllabuses and combine transdisciplinary approach to climate change problems [21]. For example, Universität Bayreuth, in cooperation with the universities of Augsburg and Würzburg, as well as in cooperation with various international organizations, offers the Master's degree in Global Change Ecology. Students consider the problem of climate change not from the point of view of individual sciences, but in their relationship [22].

\section{Conclusions}

The given investigation draws attention to general approaches of the EU and different complicated strategies of governments in separate European countries aimed at a holistic consideration of climate change phenomenon. The authors underline the necessity of reorientation of a number of laws and normative acts, which will change the orientation of all the actions to combat climate change harmful impact. At the present time we have advanced scientific instruments for account and control of climatic consequences, which have been tested enough. Nevertheless only few governments are ready to use them in national strategies as intended.

For example the climatic doctrine of Russia approved in 2009 admits the fact of global warming and the validity of the hypothesis about its human-caused nature. It underlines the necessity of the state support of scientific investigations. In 2011 the government of the Russian Federation approved a Complex Plan of Climatic doctrine implementation for the 
period till 2020. Though still there is no climatic priority in Russian policy as well as definite legislations on combating climate change. The Federal Law of the RF "On Energy Saving and Energy Efficiency" as amended on 29.07.2017 has set requirements to energy efficiency of buildings and structures. The law admits that energy efficiency should become a central element in the climatic policy, but not enough actions are taken on the level of state policy and definite measures. Moreover the fact of climate change and negative processes resulting from it are being disputed by some scientists, which is confusing Russian authorities as we believe.

The investigations show that only joint coordinated political and economic actions within a region and in the future within the planet will help slowing down the global warming process and mitigating its consequences.

The table presents the results of the study: the main areas of activity of the European Union and individual European countries in the field of climate preservation and the necessary measures to adapt of cities to climate change. The practices discussed in this article can be as an example for defining climate policy and implementing urgent actions in a city or region.

\begin{tabular}{|c|c|c|}
\hline $\begin{array}{l}\text { Directions of } \\
\text { activity }\end{array}$ & Targets and goals & Urgent actions \\
\hline $\begin{array}{l}\text { Researches in the } \\
\text { field of climate } \\
\text { change. }\end{array}$ & $\begin{array}{l}\text { - Identification of } \\
\text { climate change trends and } \\
\text { forecasting the } \\
\text { consequences of certain } \\
\text { phenomena in different } \\
\text { regions of the planet. } \\
\text { Creation of theoretical } \\
\text { models of further climate } \\
\text { change. } \\
\text { - Resolving acute } \\
\text { environmental problems } \\
\text { due to new advances in } \\
\text { science. }\end{array}$ & $\begin{array}{l}\text { 1) Development of } \\
\text { comprehensive research in the } \\
\text { field of climate change. } \\
\text { 2) State support for scientific } \\
\text { projects offering the } \\
\text { development of innovative } \\
\text { technologies and ways of } \\
\text { adapting to climate change. } \\
\text { 3) Combining the efforts of } \\
\text { scientists from different } \\
\text { countries, creating international } \\
\text { project teams. }\end{array}$ \\
\hline $\begin{array}{l}\text { Formation and } \\
\text { adoption of climate } \\
\text { legislation. }\end{array}$ & $\begin{array}{l}\text { - Adoption of timely } \\
\text { actions against climate } \\
\text { change, limitation of } \mathrm{CO} 2 \\
\text { emissions. } \\
\text { - Adaptation to the } \\
\text { consequences of climate } \\
\text { change, ensuring the } \\
\text { environmental safety of } \\
\text { territories. }\end{array}$ & $\begin{array}{l}\text { 1) Statement of a package of } \\
\text { laws on climate preservation, } \\
\text { combating global warming } \\
\text { (following the example of } \\
\text { Germany). } \\
\text { 2) Establishing legal } \\
\text { requirements for the } \\
\text { construction sector in the } \\
\text { production of building } \\
\text { materials adapted to climatic } \\
\text { and bioclimatic protection } \\
\text { goals. }\end{array}$ \\
\hline $\begin{array}{l}\text { Formulation of the } \\
\text { regional policy, the } \\
\text { strategy for } \\
\text { adaptation of } \\
\text { territories to climate } \\
\text { change. }\end{array}$ & $\begin{array}{l}\text { Joint actions of states in } \\
\text { border areas most affected } \\
\text { by the consequences of } \\
\text { climate change. }\end{array}$ & $\begin{array}{l}\text { Joining the efforts of } \\
\text { governments and municipalities, } \\
\text { creating associations to combat } \\
\text { climate change within the } \\
\text { regions, border areas (similar to } \\
\text { the initiative "Mayors Adapt"). }\end{array}$ \\
\hline
\end{tabular}




\begin{tabular}{|c|c|c|}
\hline $\begin{array}{l}\text { Development and } \\
\text { implementation of } \\
\text { programs and } \\
\text { projects for the } \\
\text { adaptation of cities } \\
\text { and territories. }\end{array}$ & $\begin{array}{l}\text { - Development of joint } \\
\text { regional programs and } \\
\text { climate change adaptation } \\
\text { projects similar to the EU } \\
\text { ADAPT project. } \\
\text { - Creating a platform to } \\
\text { inform, for more active } \\
\text { interaction between cities, } \\
\text { as well as to take joint } \\
\text { measures (for example: } \\
\text { Climate-ADAPT). }\end{array}$ & $\begin{array}{l}\text { 1) Setting norms for carbon } \\
\text { dioxide emissions in all } \\
\text { countries. } \\
\text { 2) Introduction of tax benefits } \\
\text { for the implementation of } \\
\text { measures to reduce CO2 } \\
\text { emissions (in particular, for the } \\
\text { renovation of buildings). } \\
\text { 3) The use of renewable energy } \\
\text { sources in problem areas. }\end{array}$ \\
\hline Outreach activities. & $\begin{array}{l}\text { Formation of climate } \\
\text { culture, climate and } \\
\text { environmental } \\
\text { enlightenment, upbringing } \\
\text { and education. }\end{array}$ & $\begin{array}{l}\text { 1) Involvement in a discussion } \\
\text { of urban stakeholders with } \\
\text { diverse backgrounds } \\
\text { (researchers, practitioners, } \\
\text { public administrators, planners, } \\
\text { entrepreneurs, social } \\
\text { innovators, and more). } \\
\text { 2) Creation of a platform to } \\
\text { meet, exchange, identify and } \\
\text { discuss priorities, and work } \\
\text { together on the most pressing } \\
\text { urban challenges of today and } \\
\text { the future (similar to the Joint } \\
\text { Program 'Urban Europe"). }\end{array}$ \\
\hline $\begin{array}{l}\text { Climate education } \\
\text { in schools, colleges } \\
\text { and universities }\end{array}$ & $\begin{array}{l}\text { - Formation of students' } \\
\text { competencies in the field } \\
\text { of climate change, } \\
\text { expanding students' } \\
\text { knowledge and skills. } \\
\text { - Training of high quality } \\
\text { specialists. }\end{array}$ & $\begin{array}{l}\text { Preparation of interdisciplinary } \\
\text { and cross-cutting educational } \\
\text { programs and their introduction } \\
\text { into curricula at all levels of } \\
\text { education. }\end{array}$ \\
\hline
\end{tabular}

This research was carried out under the project 620497-EPP-1-2020-1-RU-EPPJMOMODULE "Climate change and urban planning: European experience", funded with support from the European Commission. The findings and opinions reported in this paper reflect the views only of the authors, and the Commission cannot be held responsible for any use which may be made of the information contained in it.

\section{References}

1. T. M. Lee, E. M. Markovitz, P. D. Howe, et al., Predictors of public climate change awareness and risk perception around the world. Nature Climate Change, 5, 1014-1020 (2015) DOI:10.1038/nclimate2728

2. W. Poortinga, G. Böhm, L. Steg, et al., European Attitudes to Climate Change and Energy: Topline Results from Round 8 of the European Social Survey. Published by the European Social Survey ERIC City, University of London Northampton Square, London EC1V OHB, United $\quad$ Kingdom 
http://www.europeansocialsurvey.org/docs/findings/ESS8_toplines_issue_9_climatech ang.pdf (Last accessed 12.12.2020)

3. M. Nagela, M. Starkb, K. Satoha, Diversity in collaboration: Networks in urban climate change governance. Urban climate, 29, $100502 \quad$ (2019) https://doi.org/10.1016/j.uclim.2019.100502

4. D. Bray, The scientific consensus of climate change revisited. Environmental Science \& Policy, 13(5), 340-350 (2010) https://doi.org/10.1016/j.envsci.2010.04.001.

5. H. von Storch, Xue-En Chen, B. Pfau-Effinger, D. Bray, A. Ullmann. Attitudes of young scholars in Qingdao and Hamburg about climate change and climate policy - The role of culture for the explanation of differences. Advances in Climate Change Research, 10(3), 158-164 (2019) DOI: 10.1016/j.accre.2019.04.001

6. L. Gidhagen, J. Olsson, J. H. Amorim et al. Towards climate services for European cities: Lessons learnt from the Copernicus project Urban SIS. Urban Climate, 31, 100549 (2020) https://doi.org/10.1016/j.uclim.2019.100549

7. S. Grafakos, G.Viero, D.Reckien, K.Trigg et al. Integration of mitigation and adaptation in urban climate change action plans in Europe: A systematic assessment. Renewable and Sustainable Energy Reviews, 121, $109623 \quad$ (2020) https://doi.org/10.1016/j.rser.2019.109623

8. G. Özerol, N. Dolman, H. Bormann et.al., Urban water management and climate change adaptation: A self-assessment study by seven midsize cities in the North Sea Region. Sustainable Cities and Society, 55, $102066 \quad$ (2020) https://doi.org/10.1016/j.scs.2020.102066

9. A. L. Balogun, D. Marks, R. Sharma, Assessing the Potentials of Digitalization as a Tool for Climate Change Adaptation and Sustainable Development in Urban Centres. Sustainable Cities and Society, 53, $101888 \quad$ (2020) https://doi.org/10.1016/j.scs.2019.101888

10. R. P. Lejano, Climate change and the relational city. Cities, 85, 25-29 (2019) https://doi.org/10.1016/j.cities.2018.12.001

11. F. C. Aguiar, Ju. Bentz, J. M. N. Silva, A. L. Fonseca et al., Adaptation to climate change at local level in Europe: An overview. Environmental Science \& Policy, 86, 3863 (2018) https://doi.org/10.1016/j.envsci.2018.04.010

12. E. Shor, D. Roelfs, Climate shock: Moving to colder climates and immigrant mortality. Social Science \& $\quad$ Medicine, 235, 112397 https://doi.org/10.1016/j.socscimed.2019.112397

13. L. Zurita, Consensus conference method in environmental issues: relevance and strengths. Land Use Policy, 23(1), 18-25 (2006) DOI:10.1016/j.landusepol.2004.09.002

14. Li-Jin Zhong, A. P.J. Mol, Participatory environmental governance in China: Public hearings on urban water tariff setting. Journal of Environmental Management, 88(4), 899-913 (2008) https://doi.org/10.1016/j.jenvman.2007.04.018

15. Cities and Climate Change and Disaster Risk Management. Habitat III Issue Papers. New York (31 May 2015) http://habitat3.org/wp-content/uploads/Habitat-III-IssuePaper-17_Cities-and-Climate-Change-and-Disaster-Risk-Management-2.0.pdf (Last accessed 22.12.2020)

16. Territorial Agenda 2020 put in practice. Enhancing the efficiency and effectiveness of Cohesion Policy by a place-based approach. Luxembourg: Publications Office of the European Union (2015) ISBN 978-92-79-48052-2.doi:10.2776/993197. https://ec.europa.eu/regional_policy/sources/policy/what/territorial- 
cohesion/territorial_agenda_2020_practice_case_studies.pdf (Last accessed 24.12.2020)

17. ADAPT: moving towards greater resilience of cities in the face of climate change. https://ec.europa.eu/regional_policy/en/projects/italy/adapt-vers-une-plus-granderesilience-des-villes-face-au-changement-climatique (Last accessed 25.12.2020)

18. L. Gidhagen, J. Olsson, J. H.Amorim, C. Asker et al. Towards climate services for European cities: Lessons learnt from the Copernicus project Urban SIS. Urban Climate, 31, 100549 (2020) https://doi.org/10.1016/j.uclim.2019.100549

19. KfW-Energiewendebarometer 2019. Haushalte möchten mehr Erneuerbare Energien nutzen. Autoren Dr. Holger Höfling. Frankfurt am Main, August 2019. https://www.kfw.de/PDF/Download-Center/Konzernthemen/Research/PDF-

Dokumente-KfW-Energiewendebarometer/KfW-Energiewendebarometer-2019.pdf (Last accessed 25.12.2020)

20. 40 percent of Russians do not believe Greta Thunberg. https://newsobservatory.com/40percent-of-russians-do-not-believe-greta-thunberg/ (Last accessed 25.12.2020)

21. P. Molthan-Hill, N. Worsfold, G. J. Nagy, W. Leal Filho, M. Mifsud, Climate change education for universities: A conceptual framework from an international study. Journal of Cleaner Production, 226, 1092-1101 (2019) https://doi.org/10.1016/j.jclepro.2019.04.053

22. Global Change Ecology (M.Sc.) within the Elite Network of Bavaria http://www.bayceer.uni-bayreuth.de/gce/index.php?lang=en (Last accessed 25.12.2020) 